\title{
EB II-III AEGYPTIACA EAST OF THE JORDAN: A REEVALUATION OF TRADE AND CULTURAL INTERACTIONS BETWEEN EGYPT AND THE TRANSJORDANIAN URBAN CENTRES
}

\author{
Maura Sala - Sapienza University of Rome
}

Trade and cultural interconnections between pre-dynastic Egypt and the Southern Levant are established early, and most intensely since the end of the $4^{\text {th }}$ millennium $B C$, to continue in renewed forms during the $3^{\text {rd }}$ millennium BC between the Pharaonic state and the earliest urban centres of the Levant, both west and east of the Jordan.

The increasing number of Egyptian, and Egyptian-style items, identified in the first Jordanian cities of Early Bronze II-III, provides an opportunity for a reconsideration on the movement of Egyptian objects beyond the Jordan, up to the edge of the Syro-Arabian desert; on the evolution of the relations between Pharaonic Egypt and the urban centers of southern Levant in the $3^{\text {rd }}$ millennium $B C$; and, eventually, on the role these commercial and cultural interactions played in the early urban societies of the region.

Keywords: Jordan; Egypt; earliest cities; Egyptian/Egyptian-style objects; trade and cultural contacts

\section{EGYPTIAN-PALESTINIAN CONTACTS IN THE $3^{\mathrm{RD}}$ MILLENNIUM BC: AN OVERVIEW}

Exotic raw materials, as well as manufactured items (mainly luxury objects, like maceheads, palettes, shells, and beads), flowed from Egypt towards the Southern Levant as early as the $4^{\text {th }}$ millennium BC. After an initial phase of occasional exchanges during the Chalcolithic and the Early Bronze (henceforth EB) IA, ${ }^{1}$ a network of steady relationships and trade exchanges was established in EB IB in south-western Palestine, supported by the presence of Egyptian outposts (as 'Ain Besor and Tell es-Sakan), and groups of Egyptian merchants, ${ }^{2}$ with the main aim of supplying Egypt with products lacking in the motherland. Concurrently, a range of Egyptian commodities started to be traded in, and spread in Southern Levant. ${ }^{3}$

With the establishment of the Palestinian urban society in EB II-III, and the emergence of local polities, Egyptian presence in Southern Levant withdrawn. Nonetheless, EgyptianPalestinian contacts continued in a renewed form, through Egyptian emissaries supervising economic interests of the Pharaonic state in the Land of Canaan, and accomplishing commerce and diplomatic tasks between the latter and the Palestinian rulers. Stuffs that Egypt needed (as oils and resins, salt and bitumen, as well as wine) were exchanged by local elites in return for Egyptian luxury objects, ${ }^{4}$ acquired as status insignia because of

* This study moves from archaeological researches carried out by Rome "La Sapienza" Expedition to Palestine \& Jordan at the EBA site of Khirbet al-Batrawy, in North-Central Jordan.

1 De Miroschedji 2002, 40-41; Lovell 2008; Braun - van den Brink 2008, 644-659; Braun 2011, $105-110$.

2 De Miroschedji et al. 2001; de Miroschedji 2002, 41-45; Braun - van den Brink 2008, 659-672; Braun 2011, 112-119.

3 Among them, perishable goods imported from Egypt, like textiles, basketry, bones and wooden objects (as toilette articles), should be also present, even if they are often difficult to be detected in the archaeological record (Sowada 2009, 237-238)

4 De Miroschedji 2002, 45-47; Greenberg - Eisenberg 2002, 214-221; Greenberg et al. 2012, 96; Sowada 2009, 36-37, 109, 127. 
their exotic origin, precious material and sophisticated technique of manufacture: such prestige items contributed to the elite differentiation at the dawn of Palestinian urbanization. The rising presence of locally made Egyptian-style objects during the EB IIIII urban phase is similarly related to the status marking and high-level consumption of the emerging ruling class. ${ }^{5}$

\section{EGYPTIAN OBJECTS IN EB II-III SOUTHERN LEVANT}

Among the prestigious objects that streamed from Egypt to Southern Levant during the $3^{\text {rd }}$ millennium $\mathrm{BC}$, stone maceheads, calcite vessels and siltstone palettes played a prominent role. ${ }^{6}$ Stone maceheads, made of different materials, spread in Southern Levant since the Late Chalcolithic/EB I Period, mostly as ritual objects; and they continued to be acquired during the EB II-III as high status insignia. The lack of detailed petrographic analyses makes at times tentative to establish if they were Egyptian-imported or locally manufactured artefacts; nonetheless, marble, calcite, diorite and granite maceheads were definitely Egyptian importations, like the specimens retrieved at EB II-III Megiddo, ${ }^{7}$ Tell elFar'ah North $^{8}$ and Jericho 9 (for the Transjordanian samples see below $\S 3$ ).

Also Egyptian cosmetic palettes appear in Southern Levantine settlements and funerary contexts since EB IA, ${ }^{10}$ and they endured in the proto-urban EB IB in both the animalshaped and squared typology. ${ }^{11}$ Specimens retrieved in Southern Levant are basically made of siltstone, a stone locally unavailable. ${ }^{12}$ During the EB II-III, when these objects are progressively dismissed in their own motherland, ${ }^{13}$ the number of their attestations increases in the Palestinian urban centres, where palettes become wealth items of elite consumption and display, and achieve a status-related value due to their exotic origin and fine craftsmanship. ${ }^{14}$ Animal-shaped palettes present in the earlier phase (and in Egypt

5 Most exemplificative is the case of Jericho/Tell es-Sultan, where the presence of Egyptian finds, attested since the EB IA, is associated to an increasing percentage of local Egyptian-style objects during the EB II-III: Sala 2012.

6 Egyptian-imported beads and personal ornaments, primarily in carnelian, amethyst, steatite, frit/faïence or Nilotic shells, are present as well, mostly in funerary contexts.

7 Loud 1948, pl. 270:5-10.

8 Sowada 2009, 232.

$9 \quad$ Holland 1983, 804-806, fig. 365:3-5, 7, 10-11, 13 (Reg. 311, 444, 611, 710, 1048, 1116, 1449, 1593, 1781, 2922, 3194); Wheeler 1982, 630, fig. 256:1; Kenyon 1960, 171, fig. 66:4 (Reg. 151); Sala 2012, 285-286.

10 As attested to by the specimens retrieved at Gaza (de Miroschedji 1992), Meser (Dothan 1957, 226, pl. 37A), Tell el-Far'ah North (de Vaux 1951, 587, pl. XXVIIb:4 [Tomb 12]), and Jericho/Tell es-Sultan (Garstang et al. 1936, pl. XXXVI:26; Sowada 2009, 228).

11 As attested to by the specimens from EB IB contexts at Azor (Druks - Tsaferis 1970 [Tomb 40]; Ben-Tor 1975a, 28, fig. 14:1, pl. 21:2-3 [Tomb 4]), in the cemetery near 'Ain Assawir (Yannai 2002, 338, 340-341, fig. 22.1:22; Braun - van den Brink 2008, 671), and at Jericho/Tell es-Sultan (Holland 1982, 559, fig. 226:16, Reg. n. 1955; Sowada 2009, 228).

12 Siltstone/greywacke and schist were extracted in Egypt from quarries in the Eastern Desert, in use since the Pre-dynastic through the Roman Period (Astor - Harrell - Shaw 2000, 57-58; Stevenson 2007, 150-152; Klemm - Klemm 2008, 307-309; Teeter ed. 2011, 70).

13 After a series of changes, in shape as well as in destination (from functional to elitarian and ceremonial, and from burial goods to votive offerings), cosmetic palettes eventually disappear towards the end of the Naqada period ( $2^{\text {nd }}$ Dynasty); they are present in some later deposits only as heirlooms.

14 Different hypotheses have been advanced to explain this chronological divergence, suggesting that they could be either heirlooms from an earlier period, products of tombs robbing, or results of long-term exchange 
during the Naqada II period $)^{15}$ fade, and two main types are documented in the EB II-III Palestinian contexts: the squared/rectangular-shaped type, no more than $1 \mathrm{~cm}$ thick, bordered by one or two incised lines parallel to the edge, attested in Egypt since the early Naqada III period, ${ }^{16}$ like the specimen from Tell el-Khuweilfeh (stratum 14, EB III) ${ }^{17}$ and the three items from Khirbet Kerak $^{18}$ (for the Transjordanian samples see below $\S 3$ ); andthe thicker rectangular plain type, largely attested in Egypt in the Saqqara, Abu Roash, and Minshat Abu Omar necropolis of the 1-2 Dynasties, like the two specimens from EB III contexts at Khirbet Yarmouk. ${ }^{19}$ The fragment of a ceremonial siltstone palette carved with an Egyptian relief (a hand grasping a was-sceptre and 'ankh), found at Khirbet Kerak in an EB III context next to the "Circles Building", 20 is an outstanding, but up to now isolated find from Southern Levant: except of it, examples with relief-carved decorations are known only from Egypt itself, and their use seems to have been confined to the early Egyptian elites of the $0-1$ Dynasties. ${ }^{21}$

Egyptian-style palettes made by Canaanite craftsmen from local stones are also present in EB II-III contexts, as specimens from Jericho ${ }^{22}$ and Bab edh-Dhra' (§ 3) clearly illustrate. They usually exhibit a plain rectangular shape (with slightly rounded corners), with a hole drilled in the top centre, contrasting the Naqada III Egyptian-imported palettes, still attested to in EB II-III contexts (at Tell el-Khuweilfeh, Khirbet Kerak, Bab edh-Dhra“ and Numeira), which show a sharp squared shape decorated by parallel lines incised along the border. A large rectangular palette, made of siltstone, but almost certainly locally produced, was eventually found at Khirbet Yarmouk (in Area G). ${ }^{23}$

Finally, Egyptian stone vessels mostly made of calcite (the so-called "Egyptian alabaster"), ${ }^{24}$ or highly polished limestone, spread as luxury objects in Southern Levant since the beginning of the $3^{\text {rd }}$ millennium $\mathrm{BC},{ }^{25}$ mainly in temple and palatial contexts, ${ }^{26}$ as

mechanisms (Sowada 2000, 1531-1534; 2009, 243-244). Nonetheless, the recently proposed "High Chronology" for Southern Levantine EBA would at least partly shorten this temporal gap (see below $\S 4$ ).

Petrie 1974, 37-38, pls. LII-LVII; Spencer 1993, 41; Hendrickx 2006, 77-79.

16 Petrie 1974, 38, pl. LIX.

17 A handful of siltstone fragments was also found in EB III stratum 13: Jacobs 1996.

18 Greenberg - Eisenberg 2002, 214, and note 3, fig. 13.2; Sowada 2009, 121-122.

19 Sowada 2000, 1531; 2009, 104-105, fig. 19:124-125, pl. 14. One more siltstone palette, of a slightly different type, comes from EB II Arad (Amiran et al. 1978, 55, pl. 68:21), while a diorite palette was retrieved in the 1930s at 'Ai/et-Tell (Marquet-Krause 1949, 60, pls. XXXVIII:482, LXIX:482). A further trapezoidal palette, with a hole drilled in the top centre, has been recently found in an EB III context (level J-7b) at Megiddo/Tell elMutesellim (Blockman - Sass 2013, 900, fig. 15.15:538, Reg. n. 04/J/13/AR1), but its material is not specified.

20 Greenberg - Wengrow - Paz 2010; Greenberg et al. 2012, 96-97.

21 Petrie 1953, 1, 9-18, pls. A-K; Wengrow 2006, 41-44, 140-142, 176.

22 One item from an EB II layer in Tomb D12 (Kenyon 1960, 125, fig. 40:3, Reg. n. 353; Sala 2012, 284-285), three from EB II layers on the tell (Reg. ns. 2630 [Dorrell 1983, 559], 2632 [Dorrell 1983, 559, pl. 21c], and 1197 [Dorrell 1983, 559, fig. 230:12]), and another one from an EB III context on the Spring Hill (Dorrell 1983, 559, Reg. n. 3267; Sala 2012, 286).

23 Sowada 2000,1532

24 The so-called "Egyptian alabaster", i.e. calcite or travertine (also named calcite-alabaster), is not available in Southern Levant, and differs from proper alabaster, i.e. gypsum, which conversely is present in both Palestine and Transjordan (Aston - Harrell - Shaw 2000, 21,-22, 59-60; Klemm - Klemm 2008, 147).

25 Sparks 2003; Sala 2012, 279-280.

26 Sala 2008, 17-18, 69, 235-236, 302-303; Sowada 2009, 110, 216-218. 
the specimens from Arad, ${ }^{27}$ Tell el-Far'ah North, ${ }^{28}$ Khirbet Yarmouk, ${ }^{29}$ Megiddo, ${ }^{30}$ Tell el'Areini, ${ }^{31}$ and Jericho, ${ }^{32}$ up to the renowned collection of vessels from EB IIIB "Sanctuary A" at 'Ai/et-Tell, ${ }^{33}$ testify to.

\section{EGYPTIAN AND EGYPTIAN-STYLE FINDS FROM EB II-III TRANSJORDAN}

Egyptian prestigious items as stone maceheads, siltstone palettes and calcite vessels have been retrieved also east of the Jordan River. A calcite macehead from an EB II context (fig. $2: 7),{ }^{34}$ and a hippopotamus ivory cylinder seal, dating to the transitional EB II/III phase, were found at Tell Abu Kharaz; the latter was locally made, but its raw material may point to an Egyptian connection. ${ }^{35}$ A further find from the site is represented by a juglet made of Egyptian Marl Clay, though its shape belongs to the local EB II Palestinian repertoire. ${ }^{36}$

A corner fragment of a rectangular siltstone palette, with a single line incised parallel to the edge on the polished obverse, and a hole drilled in the top centre, was found in an EB III context at Numeira (fig. $2: 1$ ), ${ }^{37}$ in addition to two maceheads; ${ }^{38}$ while a handful of cosmetic palettes is said to have been uncovered at Tell el-'Umeiri (but no further information is given). ${ }^{39}$

Anyhow, the most significant group of EB II-III Egyptian and Egyptian-style objects comes from Bab edh-Dhra', probably due to strategic location of the site in an area close to the Dead Sea (procurement source of raw materials such as salt and bitumen), and the copper mines of the Wadi Faynan, and dominating the northern part of the Wadi 'Arabah joining with south-western Palestine. Here, four Egyptian palettes were found in both the settlement and the nearby necropolis: two palettes come from Field XVI (fig. 1:1-2), ${ }^{40}$ one

7 Amiran et al. 1978, 57, pl. 77:1-2; Sowada 2009, 45, fig. 5c.

28 Sowada 2009, 48-49, fig. 4a-b.

29 Ben-Tor 1975b, 72, note 26; de Miroschedji et al. 1988, 88, pl. 48:9-12; Sowada 2009, 49-50, 105-109, figs. 4c, 5a, 19-21, pl. 15.

30 Loud 1948, pl. 258:1, 262:7; Hennessy 1967, 60-61.

31 Sowada 2009, 103, fig. 20.

32 Dorrell 1983, 554, fig. 229:17, pl.19a (Reg. 1507, 1619); Sowada 2009, 49, fig. 5 b.

33 Marquet-Krause 1949, 16-21, 29; Hennessy 1967, 69-70; Amiran 1970; Callaway 1972, 299-302. Two calcite bowls were found also in the Temple of Phase A on the Acropolis (Amiran 1970, 175-179).

34 Fischer 2002, 328, fig. 21.2:5; 2008, 229, fig. 243:6. Locally made limestone maceheads were also found in phase II-III contexts (Fischer 2002, 328, fig. 21.2:4, 6-7; 2008, 68, fig. 50:1-2, 237, fig. 248:9, 359, fig. 322). For the Egyptian finds from the EB IB see below the conclusions ( $(4)$.

35 Fischer 2002, 328-330, fig. 21.3:1; 2008, 212, fig. 218:7. Two more hippopotamus ivory fragments were retrieved at Tell Abu Kharaz (Fischer 1997, 160; 2008, 358). Perhaps not by chance, the hippopotamus ivory cylinder seal was found close to an inverted conical cup with concave profile, which could be either an Egyptian import or an Egyptian-style copy (Fischer 2002, 325-327, figs. 21.1:4), and which may find parallels in the votive cups found in the EB IIIB sanctuary at 'Ai/et-Tell (Marquet-Krause 1949, pls. LIII and LXXV:1486-1488,1490,1496,1499-1502,1504,1509,1513,1526,1537-1538,1540; Hennessy 1967, 70).

36 Fischer 2002, 327, fig. 21.1:5.

37 Sowada 2000, 1528-1529, fig. 3b; 2009, 93-94, pl. 13.

38 Rast - Schaub 1989, 294.

39 Geraty et al. 1986, 135.

40 Reg. ns. 1262 and 2924: Rast - Schaub 2003, 294, fig. 10.39:2, 400, fig. 12.6:3-4; Lee 2003, 631. 
from Charnel Houses A21 (fig. 1:3), ${ }^{41}$ and another one from Charnel Houses A51 (fig. $1: 4){ }^{42}$ Egyptian-style specimens made from local stones, plain and with a hole drilled in the top centre, were also uncovered in the EB II-III tombs of the necropolis: two specimens come from Charnel Houses A22 (fig. 1:5-6), ${ }^{43}$ two from Charnel Houses A41 (fig. 1:7-8), ${ }^{44}$ and three from Charnel Houses A51 (fig. 1:9-11):.$^{45}$ they find meaningful comparisons in contemporary EB II-III local items from Jericho (see above).

Additional Egyptian and Egyptian-style finds come from Bab edh-Dhra' EB III townsite: a local cylinder seal (2860) made of pink alabaster, a material of possible Egyptian provenance (fig. 2:3), ${ }^{46}$ and a second cylinder seal (2823), made of chlorite, which is instead a confident Egyptian importation, because of both its material and decorative motif (fig. 2:2). ${ }^{47}$ A fragmentary Egyptian calcite jar has been also retrieved in Field XIV (fig. $2: 4),{ }^{48}$ while a handful of Egyptian pear-shaped maceheads, made of calcite ${ }^{49}$ and granite (fig. 2:6 $)^{50}$ comes from EB III contexts at both the town-site and the nearby necropolis. Moreover, a possible Egyptian-imported ceramic jar was found in Charnel House A22 $2^{51}$, along with predominately EB III material (fig. 2:5). ${ }^{52}$

A further item belonging to the class of Egyptian palettes recently came from EB IIIB Palace B at Khirbet al-Batrawy. This is so far the easternmost specimen of this class retrieved in Southern Levant. The Batrawy palette (KB.11.B.100) is a rectangular-shaped thin slice of grey fine schist, with an engraved line and some oblique strokes at the broken edge. $^{53}$ The Batrawy Palace gave back additional Egyptian and Egyptian-style objects, namely: a bi-conical amethyst bead, inserted in the centre of the four-strings pectoral (fig. 3:1) of gemstones necklace KB.11.B.101; ${ }^{54}$ and an Egyptian-style "Lotus Vase" (fig. 3:2). The latter belongs to the medium-sized type appearing in Southern Levant as early as EB

41 Rast - Schaub 1989, 343; Wilkinson 1989, 455, fig. 261:7.

42 Rast - Schaub 1989, 384-385; Wilkinson 1989, 454, fig. 261:3. See also Sowada 2009, 95-97, fig. 18 , pl. 13.

43 Reg. ns. 1900, 3364: Sowada 2000, 1529-1530, fig. 1c, 1e.

44 Wilkinson 1989, fig. 261:5-6.

45 Wilkinson 1989, 452-454, fig. 261:1-2, 4.

46 Lapp 1989, p. 5, fig. 4; 2003, 541-543, fig. 18.16. The motif recalls the Arad Stele, and a vessel from Bab edh-Dhra', now in the Franciscan collection at Jerusalem.

47 Lapp 1989, pp. 9-11, fig. 8; 2003, 547-550, fig. 18.21.

48 Reg. n. 1888: Lee 2003, 625, fig. 21.5:3; Sowada 2009, 99, fig. 20. A bowl rim fragment in "soft calcite" retrieved in Charnel House A21 could be also an Egyptian importation (Wilkinson 1989, 459, fig. 263).

49 Reg. ns. 752, 766, 1340. Two more calcite maceheads were found in the town-site, but out of context (Reg. ns. 1717 and 1602: Lee 2003, 624, 632, pls. 141:11, 142:10)

50 Wilkinson 1989, 459, fig. 263:4.

51 Reg. n. 2209: Rast - Schaub 1980, 39, fig. 11:3.

52 A number of beads made of different materials (such as carnelian, calcite, faience, gold, sea-shell) could be also of Egyptian origin (Sowada 2009, 94-95). Finally, a Red Sea mother-of-pearl shell pendant was found in EB II-III Charnel House 8 (Wilkinson 1989, 456, fig. 262:1)

$53 \mathrm{http} / /$ www.lasapienzatojordan.it/Discoveries\%202011/discovery2011.htm; and Nigro - Sala 2012.

54 Nigro 2012. Egyptian Eastern Desert was, in fact, the primary location for amethyst mining in pre-classical Near East (Astor - Harrell - Shaw 2000, 50-52). Extraction and working of amethyst is known in Egypt since the late Pre-dynastic period, above all in jewellery. An early source, as early as the First Dynasty, was the Wadi Abu Had, in the northern part of the Eastern Desert; while the use of most renown sources as the Gebel el-Asr and, above all, the Wadi el-Hudi dates back from the Middle Kingdom (Sadek 1980; Shaw - Jameson 1993).

55 KB.11.B.1128/76: Nigro 2013, 204. 
$\mathrm{IA}^{56}$ and well-known in south-western Palestine in the EB IB, when the presence of Egyptian and Egyptian-style pottery spread in the area. In Egypt, the "Lotus Vase" type appears from the $1^{\text {st }}$ to the $6^{\text {th }}$ Dynasty, even though attestations decrease at the time of the $5^{\text {th }}$ Dynasty. The dating of the Batrawy "Lotus Vase" to EB IIIB is, thus, much significant. The best comparisons can be found in the Egyptian-style vessels retrieved in the cachette from Temple of level J-4 at Megiddo/Tell el-Mutesellim, ${ }^{57}$ while other comparable specimens come from EB IIIB Sanctuary A at 'Ai/et-Tell, ${ }^{58}$ similarly witnessing enduring Egyptian-Palestinian cultural connections throughout the EB II-III urban phase.

\section{TRADE AND CULTURAL CONTACTS BETWEEN EGYPT AND THE EB II-III TRANSJORDANIAN URBAN CENTRES}

Occasional contacts between Egypt and the centres east of Jordan, probably through down-line trades via middlemen in Cisjordan, or sporadic visits of Egyptian merchants, occurred since the Late Chalcolithic and EB I periods: calcite (and marble?) maceheads and siltstone palette fragments from Tuleilat el-Ghassul, ${ }^{59}$ a lentoid diorite macehead from elKhawarij, ${ }^{60}$ some piriform hematite maceheads from Abu Hamid ${ }^{61}$ samples of Aspatharia rubens and a stone vase from Tall Hujayrat, ${ }^{62}$ date back to the Chalcolithic Period; while calcite and diorite maceheads come from EB IA tombs at Bab edh-Dhra '63 and, especially, two Egyptian cylindrical jars fragments and calcite and limestone maceheads were found in EB IB contexts at Tell Abu Kharaz. ${ }^{64}$

Stronger Egyptian-Jordanian connections developed in the following EB II-III phase, ${ }^{65}$ when Transjordanian settlements, which had achieved the status of urban and more

56 As attested to by two specimens from the Jericho necropolis (Kenyon's Tombs A114 and K1): Kenyon 1960, fig. 17:23; 1965, fig. 12:6; Sala 2005, 177-178.

57 Goren - Ilan 2003.

58 Marquet-Krause 1949, 195-197, pls. LII:1534,1536,1541, LXV:1524,1534,1536, LXXVI:1541; Callaway 1972, 303-304, figs. 73:1, 76:3-5.

59 Along with a number of calcite, serpentine, carnelian, ivory and faience beads: Bourke 2002, 155-156 Samples of Nilotic Aspatharia and Chambardia rubens acruata were also found at the site (Braun - van den Brink 2008, 647).

60 Lovell 2008, 749-753, figs. 4-5:a.

61 Dollfus - Kafafi 1986, 517, fig. 15:7-8, pl. 86.3-5, 7-9.

62 Klimscha - Notroff - Siegel 2014, 168-169.

63 Rast - Schaub 1989, 289-294.

64 Fischer 2002, 325-328, figs. 21.1:1-2; 2008, 49, fig. 34:5, 82, fig. 78:7, 118, fig. 119:15, 220, fig. 229:12-13, 359, fig. 322; 2014, 23-24. We can add an inverted conical cup with straight sides, either an Egyptian import or an Egyptian-style copy (Fischer 2002, 325, figs. 21.1:3); and some faience beads from a necklace (Fischer 2014, 20, fig. 3:15). The region east of the Jordan did not witness during the EB IB such an intense Egyptian frequentation as the sites of south-western Palestine, where Egyptian and Egyptian-style pottery represents up to $80 \%$ of local assemblages in centres like Tell el-'Areini and Tel Ma'ahaz (Braun 2003; Amiran - van den Brink 2002). The easternmost site outside the main area of Egyptian frequentation, showing strong Egyptian connections since EB IA, is Jericho/Tell es-Sultan, thanks to its location at one of the main ancient crossroads, and the proximity to key raw materials, as salt, sulphur and bitumen from the Dead Sea (Nigro 2008, 649-650, 653; Sala 2012, 281-284). Anyhow, the Egyptian jars and maceheads retrieved at Tell Abu Kharaz extend well beyond the Jordan River the geographical limits of the distribution of Egyptian objects during the EB I.

65 All over Southern Levant, in fact, during EB II-III, Egyptian objects start to be well attested also outside the main area of permanent Egyptian presence (i.e. south-western Palestine), pointing to a reassessment of the 
powerful centres, were able and eager to trade local raw materials (oil and wine, salt, asphalt, etc.) required by the Pharaonic state, in exchange for exotic luxury commodities: local rulers looked for valuable Egyptian artefacts (palettes, maceheads, stone vessels, etc.) as status-related insignia and forms of elite display within a developing stratified society (fig. 4). The local manufacture of Egyptian-style objects similarly accomplished the require and consumption of wealth objects by the emerging ruling class (tab. 1). The EB III collection of Egyptian and Egyptian-style objects recently found at Khirbet al-Batrawy, at the edges of the Syro-Arabic Desert, further illustrates the trade and cultural contacts acting between Egypt and the Transjordanian EB II-III urban centres, triggered by the new local polities (it is not by chance that Egyptian and Egyptian-style objects found at Khirbet alBatrawy come from the EB IIIB Royal Palace).

Such exchanges were likely negotiated by royal Egyptian agents or merchants, residing in south-western Palestine, or in a few key centres, ${ }^{66}$ and performing as liaisons between Egypt and the area to the north and to the east of the Jordan River, which laid beyond the immediate Egyptian sphere of influence.

The expanding collection of Egyptian-imported objects identified in Southern Levant, both west and east of the Jordan River, in either past or current excavations, provides an opportunity for a re-evaluation on the range, nature and extension of the relationships between Egypt and Southern Levant at the time of its first cities; on the interactions between Old Kingdom Egypt and the urban centres of $3^{\text {rd }}$ millennium BC Palestine and Transjordan; and, eventually, on the role these trade and cultural contacts played in the rising of the earliest urban culture in the region.

A larger evidence of these interactions, and Egyptian imports, is expected to be found in the archaeological record as long as analysis and identification of imported material (according to both typological and technological/petrographic studies) will improve. Diverging from what commonly and previously believed (and with the mere exception of the phenomenon of Egyptian and Egyptian-style pottery confined to EB IB south-western Palestine), the percentage of Egyptian items in Southern Levant does not decrease during the EB II-III urban phase. The number of such prestigious items appears well attested to all over Palestine and Transjordan, and its ratio does not decline moving to the north, or to the east. Key centres like Khirbet Kerak to the north, or Khirbet al-Batrawy to the farthest east, prove the continuous flow of Egyptian items towards Southern Levant up to the mid- $3^{\text {rd }}$ millennium BC (see below), within a framework of well-established cross-cultural contacts and trade relationships between the region and Old Kingdom Egypt; ${ }^{67}$ they illustrate the increasing request and consumption of such commodities by the local urban elites as rank insignia, in order to reinforce societal hierarchies and ruling status. On the other hand, the retrieval of Palestinian objects, mainly ceramic containers, in the Egyptian necropolises of

Egyptian-Palestinian relationships after the dawn of the earliest urban organizations: direct exploitation of the Palestinian products by Egyptian colonists was replaced by royal Egyptian emissaries acting as mediators in the Palestinian territory (de Miroschedji 2002, 44-47; Kafafi 2014, 151-154).

66 As it has been suggested for Khirbet Kerak: see Greenberg et al. 2012, 96-97; 2014, 94-95, 97.

67 On this topic see: Sowada 2009; Greenberg et al. 2012, 97; Nigro 2012, 231-232. 
the $1^{\text {st }}$ and $2^{\text {nd }}$ Dynasties, also points to the presence of a continuous exchange. ${ }^{68}$ Eventually, if one relies upon the newly calibrated radiocarbon dating, which fixes the end of the EB II between 3000-2900 BC, and the end of the EB III, i.e. the collapse of the earliest Palestinian cities, around the $2500 \mathrm{BC}$ (instead of $2300 \mathrm{BC}$ as previously estimated), a new synchronization pattern emerges: Palestinian EB III appears to be coeval to the earliest Old Kingdom Dynasties $\left(3^{\text {rd }}, 4^{\text {th }}\right.$, early $-5^{\text {th }}$ Dynasty), while the last phase of EB III should not continue into the $6^{\text {th }}$ Dynasty, since the collapse of the Southern Levantine urban society would take place somewhat during the $5^{\text {th }}$ Dynasty. ${ }^{69}$

Aegyptiaca retrieved in EB II-III Palestine and Transjordan may be thus interpreted as residual, or might indicate a different (higher) dating of the period (and interactions), as suggested by radiocarbon. The correlation with Egypt remains difficult for the EB II-III, when dated objects bearing reference markers diminish; anyhow, no Egyptian object later than the $5^{\text {th }}$ Dynasty has been apparently found in EB III Southern Levantine contexts. ${ }^{70}$

Egyptian-Southern Levantine interactions would be active until the mid- $3^{\text {rd }}$ millennium $\mathrm{BC}$, when they apparently dismissed following the breakdown of the Palestinian urban centres that could have happened earlier than it was traditionally retained. This is in general agreement with the evidence offered by both textual evidence ${ }^{71}$ and petrographic analyses, ${ }^{72}$ namely that since the mid- $3^{\text {rd }}$ millennium $B C$, i.e. during the late Old Kingdom $\left(5^{\text {th }}-6^{\text {th }}\right.$ Dynasties), Egypt developed stronger contacts with Central and Northern Levant, primarily centered on the flourishing EB III harbor city of Byblos. Most interesting from this point of view are the results of recent petrographic analyses from Elephantine, where imported Levantine pottery retrieved in strata of the late Old Kingdom (late $5^{\text {th }}$ - early $6^{\text {th }}$ Dynasties) came from Byblos and its surroundings, or from the area north of Tell Arqa. ${ }^{73}$

\begin{tabular}{|l|l|l|l|l|l|l|l|}
\hline \multirow{2}{*}{ Site } & \multicolumn{7}{|c|}{ Object type } \\
\cline { 2 - 8 } & \multicolumn{5}{|c|}{ Egyptian-imported } & Egyptian-style \\
\cline { 2 - 8 } & Palettes & Maceheads & $\begin{array}{l}\text { Cylinder } \\
\text { seals }\end{array}$ & $\begin{array}{l}\text { Stone } \\
\text { vessels }\end{array}$ & $\begin{array}{l}\text { Ceramic } \\
\text { vessels }\end{array}$ & Other & Vessels \\
\hline $\begin{array}{l}\text { Tell Abu } \\
\text { Kharaz }\end{array}$ & $\begin{array}{l}1 \text { (plus 3 } \\
\text { locally made) }\end{array}$ & & & 1 (?) & $\begin{array}{l}\text { raw material } \\
\text { (hippopotamus ivory) }\end{array}$ & 1 \\
\hline Tell el-'Umeiri & unspecified number & & & & & & \\
\hline Numeira & 1 & 2 & 1 & $\begin{array}{l}1 \\
\text { (plus 1?) }\end{array}$ & 1 & $\begin{array}{l}\text { raw material } \\
\text { (pink alabaster) }\end{array}$ & \\
\hline Bab edh-Dhra' & $\begin{array}{l}4 \text { (plus 7 Egyptian- } \\
\text { style palettes) }\end{array}$ & 6 & & & & 1 amethyst bead & 1 \\
\hline $\begin{array}{l}\text { Khirbet al- } \\
\text { Batrawy }\end{array}$ & 1 & & & & & & \\
\hline
\end{tabular}

Tab. 1: Summary table of Egyptian and Egyptian-style objects from EB II-III Transjordanian sites.

68 Lastly, Müller 2014, with an updated analysis of Palestinian-Egyptian contacts in light of Tomb of Den at Umm el-Qaab.

69 Regev et al. 2012; Höflmayer 2014.

70 Already Hennessy 1967; then, Chapman 2009; Sowada 2009, 123-124.

71 Marcolin - Espinel 2011.

72 Köhler - Ownby 2011; Forstner-Müller - Raue 2014.

73 Forstner-Müller - Raue 2014, 59-60. 


\section{REFERENCES}

AMIRAN R.

1970 The Egyptian stone vessel from 'Ai: Israel Exploration Journal 20 (1970), pp. 170-179.

Amiran, R. - PARAN, U. - SHILOH, Y. - Brown, R. - TSAFrir, Y. - BEN-TOR, A.

1978 Early Arad. The Chalcolithic Settlement and Early Bronze City, I. First - Fifth Seasons of Excavations, 1962-1966 (Judean Desert Studies), Jerusalem 1978.

AMIRAN, R. - VAN DEN BRINK, E.C.M.

2002 The Ceramic Assemblage from Tel Ma'ahaz, Stratum I (Seasons 1975-1976): E.C.M. VAN DEN BRINK - T.E. LEVY (eds.), Egypt and the Levant. Interrelations from the $4^{\text {th }}$ through the Early $3^{\text {rd }}$ Millennium B.C.E., London - New York 2002, pp. 273-279.

Astor, B. G. - HARRELL, J. A. - SHAw, I.

2000 Stone: P.T. Nicholson - I. Shaw (eds.), Ancient Egyptian Materials and Technology, Cambridge 2000, pp. 5-77.

BEN-TOR, A

1975a Two Burials Caves of the Proto-Urban Period at Azor: Qedem 1 (1975), pp. 1-54.

1975b The First Season of Excavations at Tell Yarmuth: August 1970: Qedem 1 (1975), pp. 5587.

BLOCKMAN, N. - SASS, B.

2013 The Small Finds: I. FinKelstein - D. Ussishrin - E. Cline (eds.), Megiddo IV. The 20042008 Seasons, Volume III (Tel Aviv Monograph Series 31), Tel Aviv 2013, pp. 866-928.

BOURKE, S.J.

2002 Teleilat Ghassul: Foreign Relations in the Late Chalcolithic Period: E.C.M. VAN DEN BRINK - TH.E. LEVY (eds.), Egypt and the Levant. Interrelations from the $4^{\text {th }}$ through the Early $3^{\text {rd }}$ Millennium B.C.E., London - New York 2002, pp. 154-164.

BRAUN, E.

2003 South Levantine encounters with ancient Egypt around the beginning of the Third Millennium: C. Rymer - R. Matthews (eds.), Ancient Perspectives on Egypt, London 2003, pp. 21-37.

2011 Early Interactions between Peoples of the Nile Valley and the Southern Levant: E. TEETER (ed.), Before the Pyramids. The origins of Egyptian Civilization (Oriental Institute Museum Publications 33), Chicago 2011, pp. 105-122.

BRAUN, E. - VAN DEN BRINK, E.C.M.

2008 Appraising South Levantine-Egyptian interaction: recent discoveries from Israel and Egypt: B. MidAnt-ReYnes - Y. TRISTANT (eds.), Egypt at its Origins 2. Proceedings of the Third International Conference "Origin of the State. Pre-dynastic and Early Dynastic Egypt", Toulouse (France), $5^{\text {th }}-8^{\text {th }}$ September 2005 (Orientalia Lovaniensia Analecta 172), Leuven - Paris - Dudley 2008, pp. 643-680.

CALlaway, J.

1972 The Early Bronze Age Sanctuary at Ai (et-Tell). A Report of the Joint Archaeological Expedition to Ai (et-Tell). No. I (Colt Archaeological Institute Publications), London 1972.

CHAPMAN, R.L.

2009 Early Bronze III and IV: Chronological and Cultural Relations: P. PARR (ed.), The Levant in Transition (The Palestine Exploration Fund Annual 9), Leeds 2009, pp. 1-8.

Dollfus, G - KAFAFI, Z.

1986 Preliminary Results of the First Season of the Jordano-French Project at Abu Hamid: Annual of the Department of Antiquities of Jordan 30 (1986), pp. 353-379. 
DORRELL, P.G.

1983 Appendix A. Stone Vessels, Tools, and Objects: K.M. KenYon - T.A. Holland, Excavations at Jericho. Volume Five. The Pottery Phases of the Tell and Others Finds, London 1983, pp. 485-575.

DOTHAN, M.

1957 Excavations at Meser, 1956. Preliminary Report on the First Season: Israel Exploration Journal 7 (1957), pp. 217-228.

DRUKS, A. - TSAFERIS, V.

$1970 \quad$ Tel Azor: Revue Biblique 77 (1970), p. 578.

FISCHER, P.

1997 Tall Abū al-Kharaz: Occupation Throughout the Ages. The Faunal and Botanical Evidence: G. Bisheh - M. Zaghloul - I. Kehrberg (eds.), Studies in the History and Archaeology of Jordan VI, Amman 1997, pp. 159-165.

2002 Egyptian-Transjordanian Interaction during Pre-dynastic and Protodynastic Times: The Evidence from Tell Abu al-Kharaz, Jordan Valley: E.C.M. VAN DEN BRINK - T.E. LEVY (eds.), Egypt and the Levant. Interrelations from the $4^{\text {th }}$ through the Early $3^{\text {rd }}$ Millennium B.C.E., London - New York 2002, pp. 323-333.

2008 Tell Abu al-Kharaz in the Jordan Valley. Volume I: The Early Bronze Age (Österreichische Akademie der Wissenschaften, Denkschriften der Gesamtakademie, Band XLVIII), Wien 2008.

2014 Primary Early Bronze Age Contexts from Tell Abu al-Kharaz, Jordan Valley: F. HöflMAYER - R. EICHMANN (eds.), Egypt and the Southern Levant in the Early Bronze Age (Orient Archäologie 31), Rahden/Westf 2014, pp. 19-56.

FORSTNER-MÜLLER, I. - RAUE, D.

2014 Contacts between Egypt and the Levant in the $3^{\text {rd }}$ Millennium BC: F. HÖFLMAYER - R. EICHMANN (eds.), Egypt and the Southern Levant in the Early Bronze Age (Orient Archäologie 31), Rahden/Westf 2014, pp. 57-67.

Garstang, J. - Ben-Dor, I. - FItzGerald, G.M.

1936 Jericho: City and Necropolis (Report for the Sixth and Concluding Season, 1936): Liverpool Annals of Archaeology and Anthropology 23 (1936), pp. 67-100.

Geraty, L.T. - L.G. Herr - LaBianca, Ø.S. - Battenfield, J.R. - Boling, R.G. - Clark, D.R. LAWLOR, J.I. - MITCHEL, L.A. - YOUNKER, R.W.

1986 Madaba Plains Project: A preliminary Report of the 1984 Season at Tell el-'Umeiri and Vicinity: Bulletin of the American Schools of Oriental Research, Supplementum 24 (1986), pp. 117-144.

GOREN, Y. - ILAN, O.

2003 The Egyptianized Pottery Vessels of Early Bronze Age Megiddo: Tel Aviv 30 (2003), pp. 42-53.

GREENBERG, R.

2014 Tel Bet Yerah - Synchronising Egyptian and South Caucasian Connections: F. HöflMAYER - R. EICHMANN (eds.), Egypt and the Southern Levant in the Early Bronze Age (Orient Archäologie 31), Rahden - Westf 2014, pp. 93-105.

GREENBERG, R. - EISENBERG, E.

2002 Egypt, Bet Yerah and Early Canaanite Urbanization: E.C.M. VAN DEN BRINK - T.E. LEVY (eds.), Egypt and the Levant. Interrelations from the $4^{\text {th }}$ through the Early $3^{\text {rd }}$ Millennium B.C.E., London - New York 2002, pp. 213-222. 
GreenberG, R. - Wengrow, D. - Paz, S.

2010 Cosmetic Connections? An Egyptian Relief Carving from Early Bronze Age Tel Bet Yerah (Israel): Antiquity (Project Gallery) 84/324 (2010) (online at: http://www.antiquity.ac.uk/ projgall/greenberg324/).

Greenberg, R. - PAZ, S. - Wengrow, D. - Iserlis, M.

2012 Tel Beth Yerah: Hub of the Early Bronze Age Levant: Near Eastern Archaeology 75 (2012), pp. 88-107.

HENDRICKX, $\mathrm{S}$

2006 Pre-dynastic-Early Dynastic Chronology: E. HorNUNG - R. KRAUSS - D.A. WARBURTON (eds.), Ancient Egyptian Chronology (Handbook of Oriental studies. Section 1, The Near and Middle East, 83), Leiden - Boston 2006, pp. 55-93.

HENNESSY, J.B.

1967 The Foreign Relations of Palestine during the Early Bronze Age, London 1967.

HÖFLMAYER, F.

2014 Egypt and the Southern Levant in the late Early Bronze Age: F. HöFLMAYER - R. EICHMANN (eds.), Egypt and the Southern Levant in the Early Bronze Age (Orient Archäologie 31), Rahden - Westf 2014, pp. 135-148.

HÖFLMAYER, F. - EichMANN, R. (eds.)

2014 Egypt and the Southern Levant in the Early Bronze Age (Orient Archäologie 31), Rahden/Westf 2014

HOLLAND, T.A.

1982 Appendix C. Figurines and Miscellaneous Objects: K.M. KenYon - T.A. Holland, Excavations at Jericho. Volume Four. The Pottery Type Series and Other Finds, London 1982, pp. 551-563.

1983 Appendix M. Stone Maceheads: K.M. KenYON - T.A. Holland, Excavations at Jericho. Volume Five. The Pottery Phases of the Tell and Others Finds, London 1983, pp. 804813.

JACOBS, P.

1996 A cosmetic palette from Early Bronze Age III at Tell Halif: J.D. SEGER (ed.), Retrieving the past: essays on archaeological research and methodology in honor of Gus W. van Beek, Winona Lake 1996, pp. 123-134.

KAFAFI, Z

2014 Early Bronze Age I-III. Archaeological Evidence from the Jordan Valley: Proof of the Levantine-Egyptian Trade Route: F. HöFlMAYER - R. EICHMANN (eds.), Egypt and the Southern Levant in the Early Bronze Age (Orient Archäologie 31), Rahden - Westf 2014, pp. 149-163.

KENYON, K.M.

1960 Excavations at Jericho. Volume One. The Tombs excavated in 1952-1954, London 1960.

1965 Excavations at Jericho. Volume Two. The Tombs excavated in 1955-1958, London 1965.

KenYon, K.M. - Holland, T.A.

1983 Excavations at Jericho. Volume Five. The Pottery Phases of the Tell and Others Finds, London 1983.

KLEMM, R. - KLEMM D.D

$2008 \quad$ Stones and Quarries in Ancient Egypt, London 2008.

Klimscha, F. - NotrofF, J. - Siegel, U.

2014 New Data on the Socio-Economic Relations between Egypt and the Southern Levant in the $4^{\text {th }}$ Millennium BC. A Jordanian Perspective: F. HöFLMAYER - R. EICHMANN (eds.), Egypt and the Southern Levant in the Early Bronze Age (Orient Archäologie 31), Rahden - Westf 2014, pp. 165-180. 
KÖHLER, E.C. - OWNBY, M.J.

2011 Levantine Imports and their Imitations from Helwan: Ägypten und Levante 21 (2011), pp. 31-46.

KROEPER, K.

1996 Minshat Abu Omar: Burials with Palettes: J. SPENCER (ed.), Aspects of Early Egypt, London 1996, pp. 70-92.

LAPP, N.

1989 Cylinder Seals and Impressions of the Third Millennium B.C. from the Dead Sea Plain: Bulletin of the American Schools of Oriental Research 273 (1989), pp. 1-15.

2003 Cylinder Seals, Impressions, and Incised Sherds: W.E. RAST - R.T. Schaub, Bâb edhDhrâ': Excavations at the Town Site (1975-1981). Part 1: Text, Part 2: Plates and Appendices (Reports of the Expedition to the Dead Sea Plain, Jordan, Volume II), Winona Lake 2003, pp. 522-565.

LEE, J.R.

2003 Worked Stones: W.E. RAST - R.T. Schaub, Bâb edh-Dhrâ': Excavations at the Town Site (1975-1981). Part 1: Text, Part 2: Plates and Appendices (Reports of the Expedition to the Dead Sea Plain, Jordan, Volume II), Winona Lake 2003, pp. 622-637. LOVELL, J.L.

2008 Horticulture, status and long-range trade in Chalcolithic Southern Levant: early connections with Egypt: B. MidANT-ReYNES - Y. TRISTANT (eds.), Egypt at its Origins 2. Proceedings of the Third International Conference "Origin of the State. Pre-dynastic and Early Dynastic Egypt", Toulouse (France), $5^{\text {th }}-8^{\text {th }}$ September 2005 (Orientalia LOUD, G. Lovaniensia Analecta 172), Leuven - Paris - Dudley 2008, pp. 741-762.

1948 Megiddo II. Seasons of 1935-39 (Oriental Institute Publications 62), Chicago 1948.

MARCOLIN, M. - ESPINEL, A.D.

2011 The Sixth Dynasty Biographic Inscriptions of Iny: More Pieces to the Puzzle: M. BÁRTA F. CopPens - J. KREJČí (eds.), Abusir and Saqqara in the Year 2010, Prague 2011, pp. $570-615$.

MARQueT-KRAUSE, J.

1949 Les fouilles de 'Ai (et-Tell) 1933-1935. La résurrection d'une grande cité biblique (Bibliothèque archéologique et historique 45), Paris 1949.

DE MirosChEDJ, P.

1992 Une palette Egyptienne prédynastique du sud de la plain côtière d'Israël: Eretz Israel 23 (1992), pp. 90*-94*.

2002 The socio-political dynamics of Egyptian-Canaanite interaction in the Early Bronze Age: E.C.M. VAN DEN BRINK - T.E. LEVY (eds.), Egypt and the Levant. Interrelations from the $4^{\text {th }}$ through the Early $3^{\text {rd }}$ Millennium B.C.E., London - New York 2002, pp. 39-57.

de Miroschedji, P. - Davis, S. - Goldberg, P. - Kermorvant, E. - Nodet, E. - Rosen, S. - London, G.

1988 Yarmouth 1. Rapport sur les trois premières campagnes de fouilles à Tel Yarmouth (Israël) (1980-1982) (Éditions Recherche sur les Civilisations, Mémoire 76), Paris 1988.

de Miroschedi, P. - Sadek, M. - Faltings, D. - Boulez, V. - Naggiar-Moliner, L. - Sykes, N. TENBERG, $\mathrm{M}$.

2001 Les fouilles de Tell es-Sakan (Gaza): nouvelles données sur les contacts égyptocananéens aux IVe-IIIe millénaires: Paléorient 27/2 (2001), pp. 75-104

MÜLLER, V.

2014 Relations between Egypt and the Near East during the 1st Egyptian Dynasty as Represented by the Royal Tomb of Den at Umm el-Qaab/Abydos: F. HöFLMAYER - R. 
EICHMAnN (eds.), Egypt and the Southern Levant in the Early Bronze Age (Orient Archäologie 31), Rahden - Westf 2014, pp. 241-258.

NigRO, L.

2008 Tell es-Sultan/Jericho from Village to Town: A Reassessment of the Early Bronze Age I Settlement and Necropolis: J.M ${ }^{A}$ CóRdOBA - M. Molist - M ${ }^{a}$ C. PÉREZ - I. RubiO - S. MARTínez (eds.), Proceedings of the $5^{\text {th }}$ International Congress on the Archaeology of the Ancient Near East (5-8 April 2006), Madrid 2008, Volume II, pp. 645-662.

2012 An EB IIIB (2500-2300 BC) gemstones necklace from the Palace of the Copper Axes at Khirbet al-Batrawy, Jordan: Vicino Oriente XVI (2012), pp. 227-243.

2013 Khirbet al-Batrawy: an Early Bronze Age city at the fringes of the desert: Syria 90 (2013), pp. 189-209.

NigRo, L. - SALA, M.

2012 Preliminary Report of the Sixth Season (2011) of Excavations by the University of Rome "La Sapienza" at Khirbat al-Batrāwī (Upper Wādī az-Zarqā'): Annual of the Department of Antiquities of Jordan 56 (2012), in press.

PETRIE, F.

1953 Ceremonial slate palettes, London 1953

$1974 \quad$ Prehistoric Egypt. Corpus of Prehistoric Pottery and Palettes, London 1974.

RAST, W.E. - SCHAUB, R.T.

1980 Preliminary Report of the 1979 Expedition to the Dead Sea Plain, Jordan: Bulletin of the American Schools of Oriental Research 240 (1980), pp. 21-61.

1989 Bâb edh-Dhrâ': Excavations in the Cemetery directed by Paul W. Lapp (1965-67) (Reports of the Expedition to the Dead Sea Plain, Jordan, Volume I), Winona Lake 1989.

2003 Bâb edh-Dhrâ': Excavations at the Town Site (1975-1981). Part 1: Text, Part 2: Plates and Appendices (Reports of the Expedition to the Dead Sea Plain, Jordan, Volume II), Winona Lake 2003.

Regev, J. - de Miroschedj, P. - Greenberg, R. - Braun, E. - Greenhut, Z. - Boaretto, E.

2012 Chronology of the Early Bronze Age in the Southern Levant: New Analysis for a High Chronology: Radiocarbon 54 (2012), pp. 525-566.

SADEK, A.I.

1980 The Amethyst Mining Inscriptions of Wadi el-Hudi, Warminster 1980.

SALA, M.

2005 Le produzioni ceramiche gerichiote del Bronzo Antico I: materiali stratificati provenienti dal tell: L. Nigro, Tell es-Sultan/Gerico alle soglie della prima urbanizzazione: il villaggio e la necropoli del Bronzo Antico I (3300-3000 a.C.) (Rome "La Sapienza" Studies on the Archaeology of Palestine \& Transjordan, 1), Roma 2005, pp. 167-196.

2008 L'architettura sacra della Palestina nell'età del Bronzo Antico I-III (Contributi e Materiali di Archeologia Orientale 13), Roma 2008.

2012 Egyptian and Egyptianizing objects from EB I-III Tell es-Sultan/ancient Jericho: Vicino Oriente 16 (2012), pp. 277-303.

SHAW, I. - JAMESON, R.

1993 Amethyst Mining in the Eastern Desert: A Preliminary Survey at Wadi el-hudi: The Journal of Egyptian Archaeology 79 (1993), pp. 81-97.

SOWADA, K.N.

2000 Egyptian Palettes in the EB II and EB III Canaan: P. MATTHIAE et alii (eds.), Proceedings of the First International Congress on the Archaeology of the Ancient Near East, Roma 2000, pp. 1527-1540.

2009 Egypt in the Eastern Mediterranean during the Old Kingdom. An Archaeological Perspective (Orbis Biblicus et Orientalis 237), Fribourg 2009. 
SPARKS, R.T.

2003 Egyptian Stone Vessels and the Politics of Exchange (2617-1070 BC): R. MATtHEws - C. SPENCER, A.J. ROOMER (eds.), Ancient Perspective on Egypt, London 2003, pp. 39-56.

1993 Early Egypt: The Rise of Civilisation in the Nile Valley, London 1993.

STEVENSON, A.

2007 The material significance of Pre-dynastic and Early Dynastic palettes: R. MAIRS - A. Stevenson (eds.), Current Research in Egyptology 2005. Proceedings of the Sixth Annual Symposium, University of Cambridge 2005, Oxford 2007, pp. 148-162.

TEETER. E. (ed.)

2011 Before the Pyramids. The origins of Egyptian Civilization (Oriental Institute Museum Publications 33), Chicago 2011.

De VAuX, R.

1951 La troisième champagne de fouilles à Tell el-Far'ah près Naplouse: Revue Biblique 58 (1951), pp. 566-590.

WHEELER, M.

1982 Appendix F. Loomweights and Spindle Whorls: K.M. KENYON - T.A. Holland, Excavations at Jericho. Volume Four. The Pottery Type Series and Other Finds, London 1982, pp. 623-637.

WENGROW, D.

2006 The archaeology of Early Egypt. Social transformations in north-east Africa, 10,000 to 2650 BC, Cambridge 2006.

WILKINSON, A.

1989 Objects from the Early Bronze II and III Tombs: W.E. RAST - R.T. ScHAUB, Bâb edhDhrâ': Excavations in the Cemetery directed by Paul W. Lapp (1965-67) (Reports of the YANNAI, E. Expedition to the Dead Sea Plain, Jordan, Volume I), Winona Lake 1989, pp. 444-470.

2002 Imported Finds from the 'Ein Assawir Tombs (Israel) and Their Significance in Understanding the Chronological Synchronization between Israel, Egypt, and Eastern Anatolia: E.C.M. VAN DEN BRINK - T.E. LEVY (eds.), Egypt and the Levant. Interrelations from the $4^{\text {th }}$ through the Early $3^{\text {rd }}$ Millennium B.C.E., London - New York 2002, pp. 334345 . 


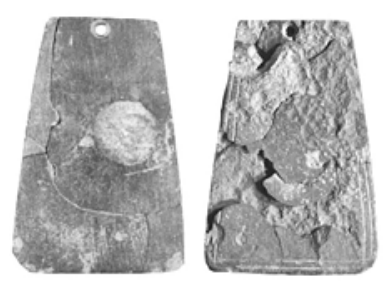

1.1262 (Field XVI)

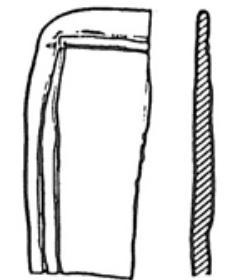

2.2924 (Field XVI)

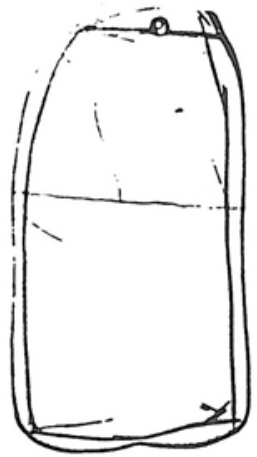

6.1900

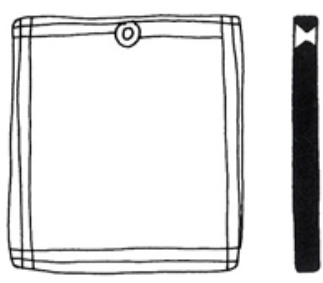

3.Charnel House A21

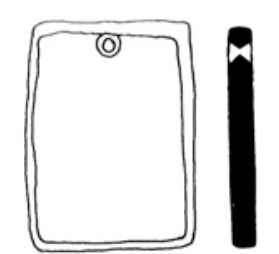

4. Charnel House A 51

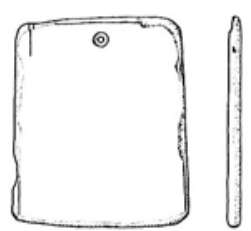

5.3364

Charnel House A22

9.

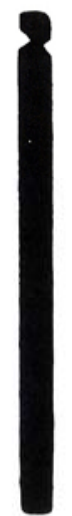

.

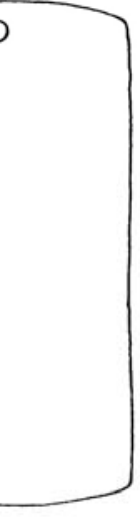

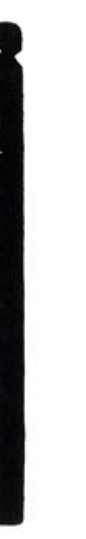
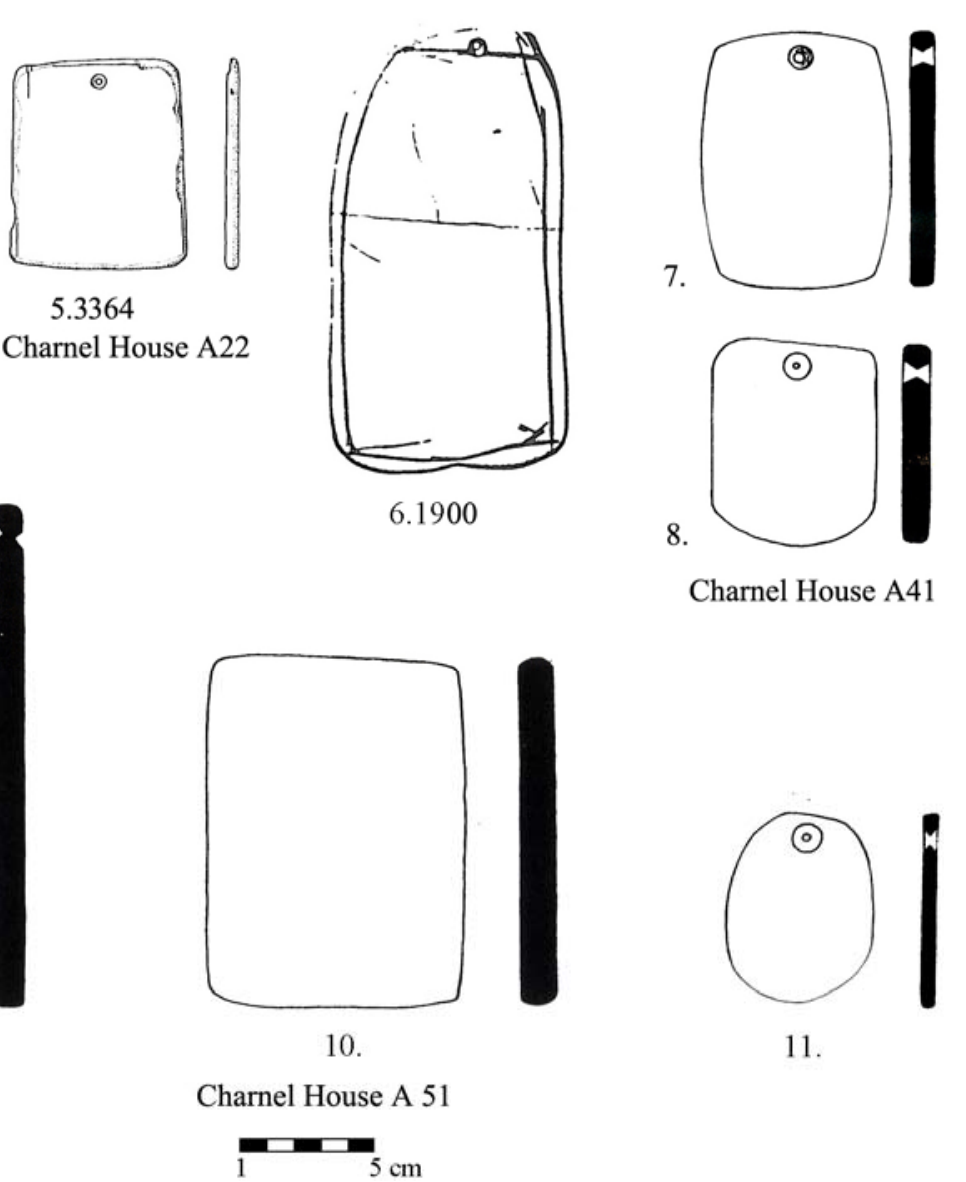

Fig. 1 - Egyptian and Egyptian-style palettes from Bab edh-Dhra' (after Wilkinson 1989, fig. 261:1-7; Sowada 2000, fig. 1c, 1e; Rast - Schaub 2003, figs. 10.39:2, 12.6:3-4). 

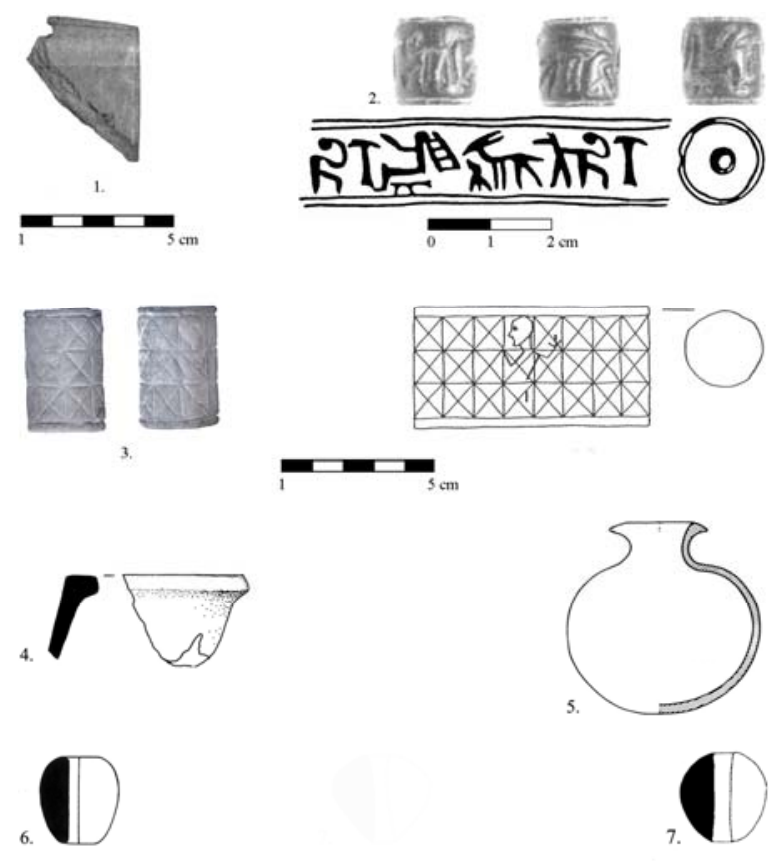

Fig. 2 - 1, Egyptian palette from Numeira (after Sowada 2000, fig. 3b); 2-3, Egyptian and Egyptian-style cylinder seals from Bab edh-Dhra' (after Lapp 2003, figs. 18.21, 18.16); 4, Egyptian calcite vessel from Bab edh-Dhra' (after Lee 2003, fig. 21.5:3); 5, Egyptian ceramic jar from Bab edh-Dhra' (after Rast - Schaub 1980, fig. 11:3); 6, Egyptian granite macehead from Bab edh-Dhra' (after Wilkinson 1989, fig. 263:4); 7, Egyptian calcite macehead from Tell Abu Kharaz (after Fischer 2008, fig. 243:6).

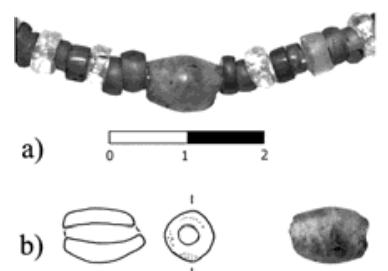

1. KB.11.B.101/i

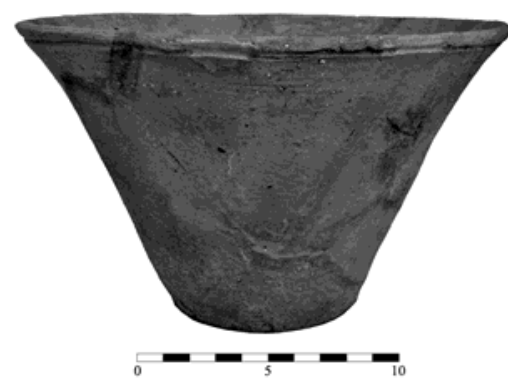

2.KB.11.B. $1128 / 76$

Fig. 3 - 1. Bi-conical amethyst bead, and 2. Egyptian-style Lotus Vase KB.11.B.1128/76 from Khirbet al-Batrawy (C Rome "La Sapienza" Expedition to Jordan). 


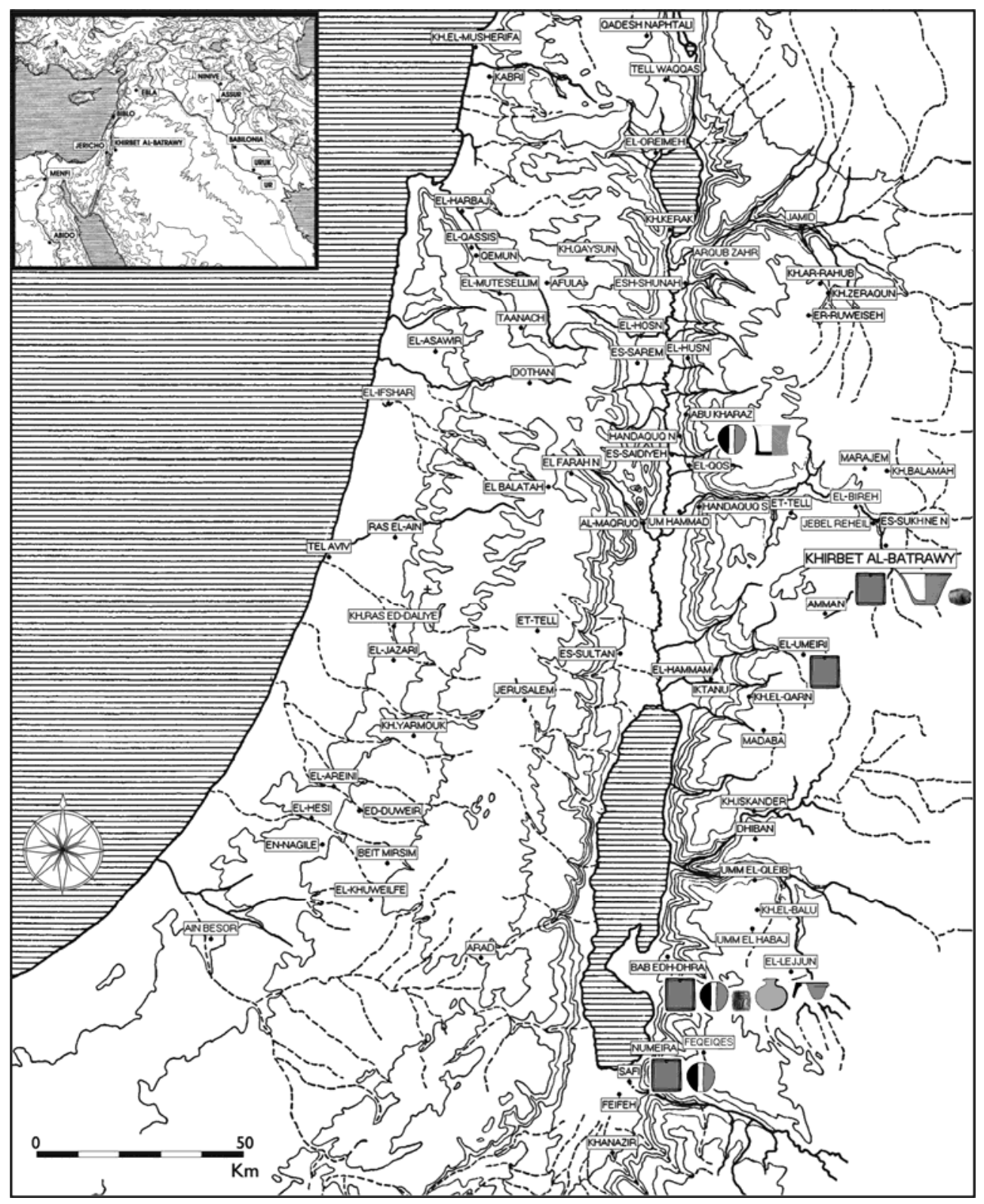

Fig. 4 - Main EB II-III Southern Levantine sites, with indicated the Egyptian and Egyptianstyle finds retrieved east of the Jordan River. 